\title{
Materialism and well-being: The Role of Consumption
}

\author{
Mario Pandelaere
}

\author{
Virginia Tech \& Ghent University
}

Mario Pandelaere is an Associate Professor of Marketing at Virginia Tech (USA) and Professor in Marketing at Ghent University (Belgium)

Address: Pamplin College of Business, Virginia Tech, 2023 Pamplin Hall, Blacksburg, VA 24061 (mpand@vt.edu). 


\title{
Highlights
}

- There is a robust, negative relation between materialism and well-being.

- A good deal of research implicates materialists' consumption style.

- Most of the negative relation may be non-consumption-related.

- Materialistic consumption may not be detrimental, depending on its motives.

\begin{abstract}
Numerous studies find a negative relation between materialism and well-being. The present paper discusses the role of consumption in that relation. First, studies on experiential versus material purchases are reviewed. While a good deal of studies find an advantage for experiential purchases, this does not occur for materialists. On the other hand, materialists do not benefit more from material than from experiential consumption due to unrealistic expectations, especially about the pleasure it affords and the impression it conveys. Still, the relation between materialism and well-being is bidirectional and the path from ill-being to materialism seems stronger. The impact of materialistic consumption on materialists' well-being may be limited and may depend on the underlying motives. Materialistic self-signaling may be especially nondetrimental for well-being.
\end{abstract}


Materialism is typically defined as the pursuit of status and happiness through the acquisition of wealth and material possessions [1]. It has also been defined as the emphasis on extrinsic goals like wealth, popularity, fame, and physical attractiveness compared to intrinsic goals like health, sense of community, and personal growth [2]. Although luxury consumption may positively affect well-being and materialists are especially likely to engage in it [3], a recent meta-analysis shows that higher levels of materialism are associated with lower levels of well-being [4]. Perhaps materialists are spending their money in the wrong way $[\mathbf{5 , 6}]$.

\section{MATERIAL VS. EXPERIENTIAL CONSUMPTION}

Materialistic consumers seem to prefer purchasing products to purchasing experiences $[\mathbf{7}, \mathbf{8}]$. However, consumption of experiences may benefit well-being more than consumption of products for several reasons $[\mathbf{9 , 1 0}]$. First, because it is less straightforward to compare experiences, one may be less likely to feel one's experiences are inferior to that of one's peers [11]. Second, experiences seem more self-expressive than products [12]. Third, as one often enjoys experiences with other people [13] and people are more likely to talk about one's experiential rather than one's material purchases [14], experiential consumption may serve the satisfaction of the basic need of relatedness. Interestingly, younger adults seem to be happier from engaging in extraordinary experiences while for older adults, any experience promote wellbeing [15]. Possibly, extraordinary experiences may better address the need of relatedness for younger adults than ordinary ones.

While experiential consumption seems to benefit well-being more than material consumption, several boundary conditions have been identified. First, the advantage of experiential consumption is limited to positive consumption outcomes; for negative outcomes, people are equally unhappy about experiences as they are about products [16]. Second, if people engage in 
experiential consumption for non-autonomous reasons (e.g., because others do it, or to make a good impression), it does not contribute to their well-being [17]. Finally, the advantages of experiential consumption are emphasized when the experience is shared with other people, not when it is enjoyed in isolation, underscoring the importance of consumption practices that both satisfy individual needs and facilitate social bonds [13].

The research on experiential consumption suggests that materialistic people would be happier if they took a more balanced approach, i.e., if they purchased more experiences. This recommendation hinges on the assumption that materialistic and non-materialistic people equally appreciate, and benefit similarly from, experiential consumption.. Several studies, however, indicate that materialism is negatively related to agreeableness and honesty-humility $[\mathbf{1 8 , 1 9 ] .}$ Materialism is also positively related to anxious attachment [20]. Anxious attachment often causes people to become lonely, which in turn leads them to pursue material goals, perhaps as a substitute for the security offered by healthy social relationships [21]. Taken together, this research suggests that materialistic people may be less willing or able to connect with other people, in which case experiential consumption may not serve the purpose of relating to other people all that much. In all, then, materialistic people may benefit less from experiential consumption than less materialistic ones.

\section{DO MATERIALISTS BENEFIT FROM EXPERIENTIAL CONSUMPTION?}

Only a handful of studies investigated whether materialism moderates the effect of material (vs. experiential) consumption on happiness. Millar and Thomas [22] find that materialistic people are happier than less materialistic people when they recall a material purchase. Interestingly, though, high and low materialistic people were equally happy with experiential purchases. However, while low materialistic people were much happier after recalling an experiential 
purchase than after recalling a material one, high materialistic people were equally happy in both conditions. As a result, the benefit of experiential (compared to material) consumption is evident for low materialistic people but not high materialistic people.

Zhang et al. [8] take a different approach to addressing whether materialism moderates the effect of type of consumption on happiness. Crucial in their research is the distinction they make between materialism as value or disposition, on the one hand, and the tendency to engage in material (vs. experiential) consumption, on the other hand. While some research suggests that materialistic consumers are more likely to engage in material consumption, being materialistic does not logically constrain people to engage in only, or even predominantly, material consumption. As such, some materialistic people may actually engage in a lot of experiential consumption too. Because of this distinction, Zhang et al. [8] investigate how materialism moderates the effect of experiential (vs. material) consumption on well-being as well as how the tendency to favor material consumption [7] moderates that relationship. While they found no moderation of the effect of experiential (vs. material) consumption on well-being, they did find that people who score low on the tendency to purchase experiences are less likely to benefit from them. Interestingly, experiential buyers were happier when buying experiences than when buying products, but material buyers were equally happy when buying experiences and products.

Although being materialistic and having a tendency to engage in material consumption are distinct conceptually, in many samples these constructs will be moderately to strongly correlated. As such, the main take-away from the studies above is that while less materialistic consumers benefit more from experiential consumption than from material consumption, highly materialistic consumers seem to benefit equally from both types of consumption. This is puzzling because materialistic people view material consumption as much more relevant than experiential 
consumption [22]; one could thus expect that material buyers would be happier buying products compared to experiences.

\section{WHY MATERIALISTS DO NOT BENEFIT MORE FROM MATERIAL CONSUMPTION}

Materialists are more likely than non-materialists to believe that the acquisition of a product will offer a lot of pleasure, improve the impression one makes on others, facilitate one's relationships with others, and help one become more efficient [23]. These expectations lead to pre-purchase anticipation which is associated with positive feelings. As many products probably fall short on their promise of significant life change, these positive feelings may diminish post-purchase. Materialists are more likely to show a decrease in positive feelings such as joy, contentment, and excitement from pre- to post-purchase than less materialistic consumers, who typically exhibit no decrease in these feelings after purchase [24].

There are several reasons why people may overestimate the pleasure they will derive from consumption. Materialistic people may be likely to splurge on big-ticket items because such items are more likely to impress other people, and because they strongly believe that price signals quality [25]. However, research has shown that it is better to spend rather frequently on small pleasures than more infrequently on large pleasures [26]. Furthermore, people often adapt quickly to improved life circumstances [27]. This applies to consumption as well. Not only do new, exciting products become pedestrian over time, any improvement in living standard may quickly become the new standard that one subsequently wants to surpass. Materialist are especially likely to want what they don't have [28], and such chronic wanting is detrimental to well-being [28, 29]. Ironically, even when materialists are very successful in their pursuit of wealth, their abundance may limit their ability to savor the better things in life [30]. 
People may signal their identity to other people through (material) consumption [31].

Materialists are especially interested in conspicuous consumption $[32,33]$, a pattern of consumption aimed at signaling one's status through luxurious and exclusive possessions. However, conspicuous consumption has ambivalent outcomes $[\mathbf{3 4}, \mathbf{3 5}]$. On the one hand, it creates impressions of competence $[\mathbf{3 4}, \mathbf{3 5}]$ and status [36], which afford associated outcomes such as others' compliance and preferential treatment [36]. At the same time, materialistic consumption is frowned upon [37] and people find conspicuous consumers of luxury brands less likeable $[\mathbf{3 4}, \mathbf{3 5}, \mathbf{3 8}]$. This may partly explain why material consumption may fail to improve one's relations with others, why materialism can cause loneliness [21], and why materialists are sometimes dissatisfied with their status products [39].

\section{MATERIALISM AND ILL-BEING: DUE TO CONSUMPTION?}

Ample research shows that materialists are, on average, not the happiest of people. While some research implicates their consumption style as contributing to their ill-being, several caveats should be noted. First, the fact that materialists seem to have inflated consumption expectations [23] seems almost inherent when one defines materialism as the belief that money and possessions buy happiness [1]. In fact, depending on how materialism is measured, the negative relation with well-being is either exacerbated or diminished [3]. The negative relation is stronger when the materialism measure includes negative traits like envy and non-generosity [40], and the pursuit of other extrinsic goals [2].

In addition, not every aspect of materialism may be detrimental. The often-used Material Values Scale [1] measures three different aspects of materialism. Research that uses this scale typically aggregates across these aspects; little research has focused on the individual aspects, and their potentially distinct relations to other variables $[\mathbf{2 1}, \mathbf{4 1 - 4 4}]$. Most relevant for the present topic, 
the belief that wealth and possessions are a road to happiness is negatively related to well-being but the belief that they signal success is not $[\mathbf{4 1}, \mathbf{4 5}, \mathbf{4 6}]$. The former belief is also positively related to debt, while the latter is negatively related to it [47]. Finally, greed is also less negatively related to well-being than materialism is $[48]$.

Literature on the advantages of experiential consumption seems to imply that materialists would be happier if they would switch from material to experiential consumption, but very few studies have tested that idea. In addition, most research relies on the approach of having consumers rate how happy they are when they recall a material versus experiential purchase [49], even though it is unclear how often people spontaneously think back on their experiential purchases. It is also possible that frequent use of material goods not only decreases how happy one is with them currently, but also how happy one thinks one was when acquiring them. Further, the research on experiential versus material consumption largely ignores how happy one is in the moment of initial acquisition or consumption, during which material purchases may outdo experiential ones [50]. The advantages of experiential consumption may thus be somewhat overstated, especially for materialists. Finally, while one may wonder why materialists are not happier with material consumption than with experiential consumption, truth of it is that they are also not less happy with the former than with the latter.

Finally, the relation between materialism and happiness not only seems bidirectional, but the relation from unhappiness to materialism seems more pronounced [21]. Insecurities [42, 51-54], feelings of powerlessness [55], low self-esteem [56, 57], social exclusion [58], financial constraints [59], relative deprivation $[\mathbf{4 1 , 6 0 , 6 1 ] ~ a n d ~ e x p o s u r e ~ t o ~ o t h e r ~ p e o p l e ' s ~ w e a l t h ~}[\mathbf{6 2}, \mathbf{6 3}]$ may all spur materialism. This suggests that a large part of materialists' unhappiness may not come from their consumption. 


\section{CONCLUSION: IS MATERIALISM NECESSARILY DETRIMENTAL?}

Shrum et al. [64] redefine materialism as "the extent to which individuals attempt to engage in the construction and maintenance of the self through the acquisition and use of products, services, experiences, or relationships that are perceived to provide desirable symbolic value" (p. 1180). This definition not only broadens the concept of materialism but also renders it outcomeneutral. Everybody is to some extent materialistic, and materialistic consumption may not necessarily be bad. It may largely depend on the motives for it. Materialists' concern with the impressions they make on others implies that their spending behavior is not fully autonomous, and hence, may not serve their need for autonomy. However, Shrum et al. hypothesize that materialism may not be detrimental for well-being if it involves self-signaling instead of othersignaling.

When people signal to themselves rather than to other people, the likelihood that the image they want to project will be disconfirmed is probably much lower. In addition, people are less likely to be confronted with potential negative reactions as self-signaling may involve private consumption. More importantly, self-signaling seems more autonomous than other-signaling and, as such, may serve the need for autonomy. Finally, as self-signaling is probably much more expressive of one's true self, it may lead to less satiation [65]. If people are less frustrated with the outcomes of their consumption and satiate more slowly, perhaps this may slow down the frequency of spending. In addition to slowing down hedonic adaptation [66], it may also alleviate the problem of overspending and debt that typically results from a materialistic lifestyle $[\mathbf{2 3 , 4 6 ,}$ 66-68]. This speculation is left for future research. 


\section{REFERENCES}

1. *Richins, M. L., \& Dawson, S. (1992). A consumer values orientation for materialism and its measurement: Scale development and validation. Journal of Consumer Research, $19,303-316$.

Most used scale to measure materialism. Distinguishes between three facets of materialism but these are often aggregated in research.

2. *Kasser, T., \& Ryan, R. M. (1996). Further examining the American dream: Differential correlates of intrinsic and extrinsic goals. Personality and Social Psychology Bulletin, 22, $280-287$.

A non-consumer perspective on materialism derived from self-determination theory. Includes goals that are not directly tied to either money or consumption.

3. Hudders, L. \& Pandelaere, M. (2012). The Silver Lining of Materialism: The Impact of Luxury Consumption on Subjective Well-Being. Journal of Happiness Studies, 13 (3), 411-437.

One of the first papers to look at the positive consequences of materialism. It shows that materialists benefit more from luxury consumption than non-materialists. Despite that, materialists are less happy than non-materialists.

4. *Dittmar, H., Bond, R., Hurst, M., \& Kasser, T. (2014). The relationship between materialism and personal well-being: A meta-analysis. Journal of personality and social psychology, 107(5), 879. 
Very thorough meta-analysis that underscores the robustness of the negative relation between materialism and well-being. Very few moderators are discovered and irrespective of any moderation, the relation stays negative.

5. *Dunn, E. W., Gilbert, D. T., \& Wilson, T. D. (2011). If money doesn't make you happy, then you probably aren't spending it right. Journal of Consumer Psychology, 21(2), 115125.

Very good overview of the different ways that spending money can contribute to happiness.

6. Kashdan, T.B., \& Breen, W.E. (2007). Materialism and diminished well-being: Experiential avoidance as a mediating mechanism. Journal of Social and Clinical Psychology, 26, 521-539.

7. Howell, R. T., Pchelin, P, \& Iyer, R. (2012). The preference for experiences over possessions: Measurement and construct validation of the experiential buying tendency scale. The Journal of Positive Psychology, 7, 57-71.

8. Zhang, J., Howell, R.T., Caprariello, P.A., \& Guevarra, D.A. (2014). Damned if they do, damned if they don't: Material buyers are not happier from material or experiential consumption. Journal of Research in Personality, 50, 71-83.

9. *Gilovich, T., \& Kumar, A. (2015). We'll always have Paris: The Hedonic Payoff from Experiential and Material Investments. In M.P. Zanna and J.M. Olson (Eds.), Advances in experimental social psychology, Vol. 51, AESP, UK: Academic Press. 
Extremely thorough overview of the literature on experiential versus material consumption, with a good introduction to literature on the relation between income and happiness.

10. *Gilovich, T., Kumar, A., \& Jampol, L. (2015). A wonderful life: Experiential consumption and the pursuit of happiness. Journal of Consumer Psychology, 25(1), 152165.

More concise description of the ideas discussed in the chapter above.

11. Carter, T. J., \& Gilovich, T. (2010). The relative relativity of material and experiential purchases. Journal of Personality and Social Psychology, 98(1), 146-159.

12. Carter, T. J., \& Gilovich, T. (2012). I am what I do, not what I have: The centrality of experiential purchases to the self-concept. Journal of Personality and Social Psychology, 102(6), 1304-1317.

13. Caprariello, P. A., \& Reis, H. T. (2013). To do or to have, or to share? Valuing experiences over material possessions depends on the involvement of others. Journal of Personality and Social Psychology, 104(2), 199-215.

Paper showing how important sharing with other people is for the experiential advantage to occur.

14. Amit Kumar and Thomas Gilovich. (2015). Some "Thing" to Talk About? Differential Story Utility From Experiential and Material Purchases. Personality and Social Psychology Bulletin, 41, 1320-1331.

15. Bhattacharjee, A., \& Mogilner, C. (2014). Happiness from ordinary and extraordinary experiences. Journal of Consumer Research, 41, 1-17. 
16. Nicolao, L., Irwin, J. R., \& Goodman, J. K. (2009). Happiness for sale: Do experiential purchases make consumers happier than material purchases? Journal of Consumer Research, 36(2), 188-198.

17. Zhang, J. W., Howell, R. T., \& Caprariello, P. A. (2013). Buying life experiences for the "right" reasons: A validation of the Motivations for Experiential Buying Scale. Journal of Happiness Studies, 14(3), 817-842.

18. Lee, K., Ashton, M. C., Wiltshire, J., Bourdage, J. S., Visser, B. A., \& Gallucci, A. (2013). Sex, power, and money: Prediction from the Dark Triad and Honesty-Humility. European Journal of Personality, 27(2), 169-184.

19. Watson, D. C. (2014). Materialism: Profiles of agreeableness and neuroticism. Personality and Individual Differences, 56, 197-200.

20. Norris, J. I., Lambert, N. M., DeWall, C. N., \& Fincham, F. D. (2012). Can’t buy me love?: Anxious attachment and materialistic values. Personality and Individual Differences, 53(5), 666-669.

21. *Pieters, R. (2013). Bidirectional dynamics of materialism and loneliness: Not just a vicious cycle. Journal of Consumer Research, 40(4), 615-631.

One of the few longitudinal studies that allows disentangling the I;pact of materialism on happiness and vice versa.

22. Millar, M., \& Thomas, R. (2009). Discretionary activity and happiness: The role of materialism. Journal of Research in Personality, 43(4), 699-702.

23. Richins, M. L. (2011). Materialism, transformation expectations, and spending: Implications for credit use. Journal of Public Policy \& Marketing, 30(2), 141-156. 
Introduces the concept of transformation expectations, the idea that people think that consumption may profoundly change an aspect of their lives.

24. *Richins, M. L. (2013). When wanting is better than having: Materialism, transformation expectations, and product-evoked emotions in the purchase process. Journal of Consumer Research, 40(1), 1-18.

Follow-up of the paper above. Tracks how emotions develop over time as a function of transformation expectations.

25. Christandl, F., Lotz, S, Pandelaere, M., \& Fetchenhauer, D. (in preparation). Why Materialists Prefer Expensive Goods: The Role of Price-Quality Beliefs.

26. Zhong, J. Y., \& Mitchell, V. W. (2010). A mechanism model of the effect of hedonic product consumption on well-being. Journal of Consumer Psychology, 20(2), 152-162.

27. Frederick, S., \& Loewenstein, G. (1999). Hedonic adaptation. In D. Kahneman, E. Diener, \& N. Schwarz (Eds.), Well-being: The foundations of hedonic psychology (pp. 302-329). New York: Russell Sage Foundation.

Very solid overview of the problem of adapting the changed life circumstances.

28. Norris, J. I., \& Larsen, J. T. (2011). Wanting more than you have and its consequences for Well-being. Journal of Happiness Studies, 12(5), 877-885.

29. Larsen, J. T., \& McKibban, A. R. (2008). Is happiness having what you want, wanting what you have, or both? Psychological Science, 19, 371-377.

Nice idea that is being pursued on wanting not necessarily being negative. 
30. Quoidbach, J., Dunn, E. W., Petrides, K. V., \& Mikolajczak, M. (2010). Money Giveth, Money Taketh Away The Dual Effect of Wealth on Happiness. Psychological Science, $21,759-763$.

Very interesting paper that shows how wealth may undermine some of the benefits it brings.

31. *Belk, R.W. (1988). Possessions and the extended self. Journal of Consumer Research, $15,139-168$.

Classic paper on how people can use possessions to signal and cultivate an image.

32. Richins, M. (1994). Special Possessions and the Expression of Material Values. Journal of Consumer Research, 21, 522-533.

33. Wong, N. Y. C. ( 1997). Suppose you own the world and no one knows? Conspicuous consumption, materialism and self. In M. Brucks \& D. MacInnis (Eds.), Advances in consumer research (Vol. 24, pp. 197-201). Provo, UT: Association for Consumer Research.

34. Scott, M. L., Mende, M., \& Bolton, L. E. (2013). Judging the book by its cover? How consumers decode conspicuous consumption cues in buyer-seller relationships. Journal of Marketing Research, 50(3), 334-347.

35. Christopher, A. N., \& Schlenker, B. R. (2000). The impact of perceived material wealth and perceiver personality on first impressions. Journal of Economic Psychology, 21(1), 119.

36. Nelissen, R. M., \& Meijers, M. H. (2011). Social benefits of luxury brands as costly signals of wealth and status. Evolution and Human Behavior, 32(5), 343-355. 
37. *Van Boven, L., Campbell, M. C., \& Gilovich, T. (2010). Stigmatizing materialism: On stereotypes and impressions of materialistic and experiential pursuits. Personality and Social Psychology Bulletin, 36(4), 551-563.

38. McFerran, B., Aquino, K., \& Tracy, J. L. (2014). Evidence for two facets of pride in consumption: Findings from luxury brands. Journal of Consumer Psychology, 24(4), $455-471$.

39. Wang, J., \& Wallendorf, M. (2006). Materialism, status signaling, and product satisfaction. Journal of the Academy of Marketing Science, 34, 494-505.

40. *Belk, R. W. (1985). Materialism: Trait aspects of living in the material world. Journal of Consumer Research, 12, 265-280.

One of the seminal papers on materialism. Introduces one of the prominent measures on materialism.

41. Ahuvia, A. C., \& Wong, N. Y. (2002). Personality and values based materialism: Their relationship and origins. Journal of consumer psychology, 12(4), 389-402.

42. Chang, L., \& Arkin, R. M. (2002). Materialism as an attempt to cope with uncertainty. Psychology \& Marketing, 19(5), 389-406.

43. Donnelly, G., Iyer, R., \& Howell, R. T. (2012). The Big Five personality traits, material values, and financial well-being of self-described money managers. Journal of Economic Psychology, 33(6), 1129-1142.

44. Roberts, J. A., Manolis, C., \& Tanner, J. F. J. (2003). Family structure, materialism, and compulsive buying: A reinquiry and extension. Journal of the Academy of Marketing Science, 31(3), 300-311. 
45. Lens, I., Pandelaere, M., Shrum, L. J., \& Lee, J. (2012). Keeping up vs. getting ahead: How different dimensions of materialism reflect different underlying motivations and produce different consumption preferences and choices. In S. Botti, V. Morwitz, \& S. Puntoni (Eds.), International advances in consumer psychology. Florence: Society for Consumer Psychology.

46. Gardarsdottir, R. B., Dittmar, H., \& Aspinall, C. (2009). It's not the money, it's the quest for a happier self: the role of happiness and success motives in the link between financial goals and subjective well-being. Journal of Social and Clinical Psychology, 28(9), 1100.

47. Nepomuceno, M. V., \& Laroche, M. (2015). The impact of materialism and anticonsumption lifestyles on personal debt and account balances. Journal of Business Research, 68(3), 654-664.

48. Krekels, G., \& Pandelaere, M. (2015). Dispositional greed. Personality and Individual Differences, 74, 225-230.

Introduces a scale to measure individual differences in greed.

49. *Van Boven, L., \& Gilovich, T. (2003). To do or to have? That is the question. Journal of personality and social psychology, 85(6), 1193.

Seminal paper on the distinction between material and experiential consumption.

50. Dunn, E. W., \& Weidman, A. C. (2015). Building a science of spending: Lessons from the past and directions for the future. Journal of Consumer Psychology, 25(1), 172-178.

51. Rindfleisch, A., Burroughs, J. E., \& Denton, F. (1997). Family structure, materialism, and compulsive consumption. Journal of consumer research, 312-325. 
52. Kasser, T., \& Sheldon, K. M. (2000). Of wealth and death: Materialism, mortality salience, and consumption behavior. Psychological science, 11(4), 348-351.

53. Christopher, A. N., Drummond, K., Jones, J. R., Marek, P., \& Therriault, K. M. (2006). Beliefs about one's own death, personal insecurity, and materialism. Personality and Individual Differences, 40(3), 441-451.

54. *Twenge, J. M., \& Kasser, T. (2013). Generational Changes in Materialism and Work Centrality, 1976-2007 Associations With Temporal Changes in Societal Insecurity and Materialistic Role Modeling. Personality and Social Psychology Bulletin, 39(7), 883-897.

55. Rucker, D. D., \& Galinsky, A. D. (2008). Desire to acquire: Powerlessness and compensatory consumption. Journal of Consumer Research, 35(2), 257-267.

56. Sivanathan, N., \& Pettit, N. C. (2010). Protecting the self through consumption: Status goods as affirmational commodities. Journal of Experimental Social Psychology, 46(3), $564-570$.

57. Chaplin, L. N., \& John, D. R. (2007). Growing up in a material world: Age differences in materialism in children and adolescents. Journal of Consumer Research, 34(4), 480-493.

58. Lee, J., \& Shrum, L. J. (2012). Conspicuous consumption versus charitable behavior in response to social exclusion: A differential needs explanation. Journal of Consumer Research, 39(3), 530-544.

59. Tully, S. M., Hershfield, H., \& Meyvis, T. (2015). Seeking Lasting Enjoyment with Limited Money: Financial Constraints Increase Preference for Material Goods Over Experiences. Journal of Consumer Research, 42 (1): 59-75.

60. Sharma, E., \& Alter, A. L. (2012). Financial deprivation prompts consumers to seek scarce goods. Journal of Consumer Research, 39(3), 545-560. 
61. Zhang, H., Tian, Y., Lei, B., Yu, S., \& Liu, M. (in press). Personal Relative Deprivation Boosts Materialism. Basic and Applied Social Psychology, DOI:10.1080/01973533.2015.1072090.

62. Zhang, J. W., Howell, R. T., \& Howell, C. J. (2014). Living in wealthy neighborhoods increases material desires and maladaptive consumption. Journal of Consumer Culture, 1469540514521085.

63. Hudders, L., \& Pandelaere, M. (2014). Is Having a Taste of Luxury a Good Idea? How Use vs. Ownership of Luxury Products Affects Satisfaction with Life. Applied Research in Quality of Life, 10(2), 253-262.

64. *Shrum, L. J., Wong, N., Arif, F., Chugani, S. K., Gunz, A., Lowrey, T. M., ... \& Sundie, J. (2013). Reconceptualizing materialism as identity goal pursuits: Functions, processes, and consequences. Journal of Business Research, 66(8), 1179-1185.

a. Offers an alternative, more neutral concept of materialism.

65. Chugani, S. K., Irwin, J. R., \& Redden, J. P. (in press). Happily Ever After: The Effect of Identity-Consistency on Product Satiation. Journal of Consumer Research. DOI:

\section{http://dx.doi.org/10.1093/jcr/ucv040}

66. Chancellor, J., \& Lyubomirsky, S. (2011). Happiness and thrift: When (spending) less is (hedonically) more. Journal of Consumer Psychology, 21(2), 131-138.

67. Watson, J. J. (2003). The relationship of materialism to spending tendencies, saving, and debt. Journal of economic psychology, 24(6), 723-739.

68. Garðarsdóttir, R. B., \& Dittmar, H. (2012). The relationship of materialism to debt and financial well-being: The case of Iceland's perceived prosperity. Journal of Economic Psychology, 33(3), 471-481. 
* Must-reads on materialism and material consumption 